\title{
Carbon Characterization of Size-Segregated Particulate Matters (PMs) in Residential and Educational Areas in Padang City, Indonesia
}

\author{
Muhammad Amin'1, Rahmi Mulia Putri', Fadjar Goembira², Mitsuhiko Hata3, \\ Masami Furuuchi ${ }^{3,4^{*}}$ \\ ${ }^{1}$ Graduate School of Natural Science and Technology, Kanazawa University, Kanazawa, Ishikawa, Japan \\ ${ }^{2}$ Department of Environmental Engineering, Faculty of Engineering, Andalas University, Padang, Sumatera Barat, \\ Indonesia \\ ${ }^{3}$ Faculty of Geoscience and Civil Engineering, Institute of Science and Engineering, Kanazawa University, Kanazawa, Ishikawa, \\ Japan \\ ${ }^{4}$ Faculty of Environmental Management, Prince of Songkla University, Hat Yai, Songkhla, Thailand \\ Email: *mfuruch@staff.kanazawa-u.ac.jp
}

How to cite this paper: Amin, M., Putri, R. M., Goembira, F., Hata, M., \& Furuuchi, M. (2021). Carbon Characterization of SizeSegregated Particulate Matters (PMs) in Residential and Educational Areas in $\mathrm{Pa}$ dang City, Indonesia. Journal of Geoscience and Environment Protection, 9, 225-238. https://doi.org/10.4236/gep.2021.98015

Received: August 5, 2021

Accepted: August 28, 2021

Published: August 31, 2021

\begin{abstract}
Size-segregated of particulate matter (PM) including $\mathrm{PM}_{0.1}$ at two different sites, i.e., educational (EA) and residential (RA) areas in Padang city, Indonesia were sampled by using a cascade type air sampler for 24 hours with the average flowrate $40 \mathrm{l} / \mathrm{m}$ throughout three weeks (March, $08^{\text {th }}-25^{\text {th }}$ 2018). Carbonaceous components were analyses by a carbon analyzer following the IMPROVE_TOR protocol. Average $\mathrm{PM}_{2.5}$ and $\mathrm{PM}_{10}$ concentrations in RA were higher than those in EA while being below the NAAQS of Indonesia. However, it was much higher compared to the WHO limit for 24 hours in RA. OC was the dominant fraction in TC. OC/EC ratio ranging from 2.4 to 33.0 was similar at both sites, suggesting the $\mathrm{OC}$ was emitted from various sources. Char-EC and soot-EC ratio were founded to be minimized for $\mathrm{PM}_{0.1}$ $(0.40 \pm 0.27$ and $0.39 \pm 0.39$, respectively at each site), indicating a more influence of burning of fossil fuel as vehicles exhaust and coal combustion. The transboundary influence of open biomass burning was not so significant although it cannot be ignored.
\end{abstract}

\section{Keywords}

Size-Segregated Particle, $\mathrm{PM}_{0.1}$, Residential, Educational, Carbon Component, Indonesia

\section{Introduction}

As similar to many countries in the world, air pollution is one of the biggest en- 
vironmental problems in Indonesia, for instance, the emission from industrial activities and transportation. Those two sectors use a great amount of fuel and kind of materials that could emit a huge amount of particulate matters (PMs) to the atmosphere and polluted the residential area nearby (Reddington et al., 2019). Not only those two sectors, but open biomass burning also has a great impact on the higher PMs concentration in the atmospheric environment of Indonesia particularly from the crop residue burning and forest and/or peatland fires (Oanh et al., 2018).

Many published documents proved that PMs has a harmful effect both for human and environment such as respiratory and global warming, respectively (Manisalidis et al., 2020) because it contains a lot of chemical composition particularly carbonaceous component. Carbonaceous aerosol could be divided into organic carbon (OC) and elemental carbon (EC) (Zhang et al., 2020). OC contains an abundance of organic compounds and produced by primary emission, i.e. vehicular emission, coal combustion, and biomass burning, and by secondary formation via conversion process from gas to the article of volatile organic compounds (VOCs) while EC is an important light-absorbing component in the atmosphere which derived from incomplete combustion of carbon-containing materials (Tao et al., 2021). Those two-carbon contents are the primary component in the PMs which account for $45 \%-60 \%$ of $\mathrm{PM}_{0.1}, \mathrm{PM}_{2.5}$, and $\mathrm{PM}_{10}$ (Thuy et al., 2018).

Taking into account PMs research in Indonesia, several studies have focused on the emission from transportation (Kusumaningtyas et al., 2018). Then, some published documents have been studied related to the forest/peatland fire (Fujii et al., 2019), and a few more documents analyzed the PMs emitted from the factory (Bachtiar et al., 2016). However, all of the documents published have concerned only on fine and coarse particles larger than submicron meter. Studied related to ultrafine particles or $\mathrm{PM}_{0.1}$ are still rare in Indonesia.

Furthermore, as to the chemical composition of PMs in Indonesia, some studies focused on trace elements (Bachtiar et al., 2016; Fujii et al., 2019) and a few research studies about carbon components in the fine and coarse particles emitted from forest/peatland fires (Adam et al., 2021). Nonetheless, there is a lack of detailed analyses on the size-segregated of carbon content including ultrafine particle Indonesia, particularly in the educational and residential areas.

Thus, the aims of this work were to evaluate the mass of size-segregated PMs including ultrafine, fine, and coarse particles collected at educational and residential areas in Padang city and to characterize the size distribution of carbonaceous components including OC, EC, total carbon (TC), char-EC and soot-EC, and to reinforce the ambient carbon database of Indonesia, particularly, of $\mathrm{Pa}$ dang city.

\section{Methodology}

\subsection{Study Area}

We selected the location based on two different characteristic sites i.e. an educa- 
tional and a residential area which have a possible influenced from various emission sources nearby as shown in Figure 1. The first sampling site was located in the $4^{\text {th }}$ floor of Environmental Engineering Division, Faculty of Engineering, Andalas University $\left(00^{\circ} 54^{\prime} 46.3^{\prime \prime S} 100^{\circ} 27^{\prime} 50.0^{\prime \prime} \mathrm{E}, 144.8 \mathrm{~m}\right.$ a.s.l). Andalas University is the largest University in Sumatera Island which located in the top of the Limau Manis hill, around $\pm 3.41 \mathrm{~km}$ from the second sampling site and \pm 3.65 $\mathrm{km}$ from Cement Factory. In 2019, the total of active students at Andalas University was around 25,806 students and 3082 of them have registered in the Engineering faculty.

Furthermore, the second study area is situated in the northwest of Cement Factory $( \pm 1.3 \mathrm{~km})$ and north of Padang Basi Street $( \pm 1.2 \mathrm{~km})$ which located on the rooftop of one of the resident's houses in Unand B Block residential area ( $\left.0^{\circ} 56^{\prime} 30.7^{\prime \prime} \mathrm{S} 100^{\circ} 27^{\prime} 17.0^{\prime \prime} \mathrm{E}\right), 284.7 \mathrm{~m}$ above sea level (a.s.l), Limau Manis Selatan Village, in Pauh Subdistrict of Padang city. The site was $\pm 10.62 \mathrm{~km}$ from the city center. The total area of Limau Manis Selatan Village is around $12.96 \mathrm{Ha}$ and around 11,663 total residence in 2018. As to the land use, the Pauh subdistrict area has used for field rice $(991 \mathrm{Ha})$, garden $(464 \mathrm{Ha})$, dry field rice $(219 \mathrm{Ha})$, community forest $(1927 \mathrm{Ha})$, unused $(110 \mathrm{Ha})$, fish fond, state forest and others $(10,366 \mathrm{ha})$ and non-agriculture i.e. road, residential area, institution, industrial area account $552 \mathrm{Ha}$ (BPS Padang City, 2019). Cement factory nearby sampling site is the first cement factory in Indonesia (established in 1910) and the total production is more than million tons per year. Feedstock such as coal, gypsum, and limestone are the primary raw materials in the production of cement in Indonesia.

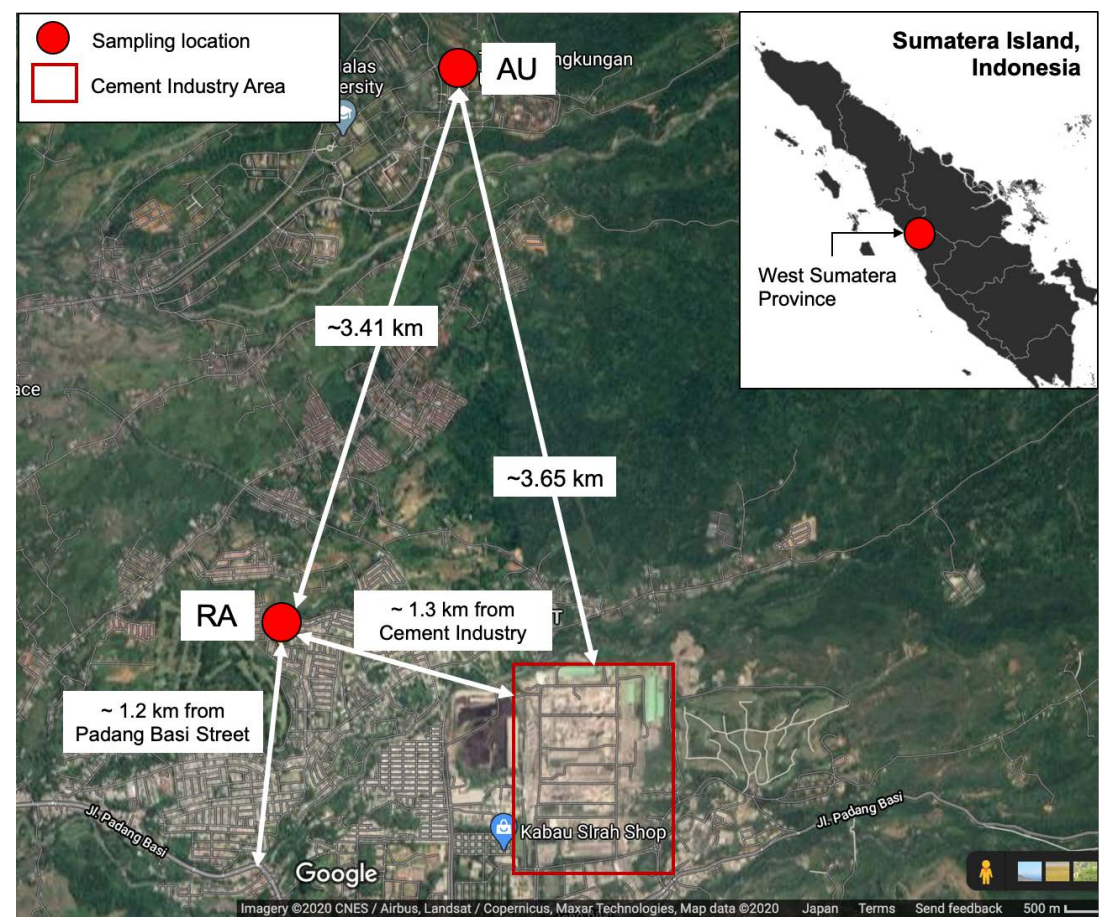

Figure 1. Sampling site in educational and residential areas in Padang city. 
Published by Padang Statistical Agency (2019) (BPS Padang City, 2019), respiratory disease is the biggest number of patients in the Pauh Subdistrict which around 7.7 percent (5690 patients) of the total population $(74,141)$.

\subsection{Sampling Time and Instrument for Aerosol Measurement}

Ambient Nano Sampler (ANS), a cascade air applicable to $\mathrm{PM}_{0.1}$, developed by Furuuchi et al. (2010) was used for air sampling to collect the particle in Padang city, Indonesia. The sampler consists of four impactor stages to collect the particle $>10 \mu \mathrm{m}, 10-2.5 \mu \mathrm{m}, 2.5-1 \mu \mathrm{m}, 1-0.5 \mu \mathrm{m}$, respectively from the top to the bottom of the sampler, and an inertial filter (IF) stage to specify the particle 0.5 $0.1 \mu \mathrm{m}$ before going down to the last stage called backup filter (BF) as the container of particle smaller than $0.1 \mu \mathrm{m}\left(\mathrm{PM}_{0.1}\right)$. A $55-\mathrm{mm}$ quartz fibrous filter (QFF) (Pallflex, 2500 QAT-UP) was used for collection in each stage except for the IF stage which used a stainless-steel filter packed in an IF (SUS304, fiber diameter $=9.8 \mu \mathrm{m}$ ). Furthermore, the QFF filters were preheated at $350^{\circ} \mathrm{C}$ to ignore the possible contaminant and kept it in the weighing chamber around 48 hours at a stable temperature and relative humidity at $21.5^{\circ} \mathrm{C} \pm 1.5^{\circ} \mathrm{C}$ and $35 \% \pm$ $5 \%$, respectively before and after sampling (PWS-PM2.5, Tokyo Dylec Corp., Japan) following the procedure standard published by Ministry of Environment of Japan (2019) (MOE, 2019). 75 QFFs and 15 IFs were used in this study for around there weeks from $14^{\text {th }}$ to $25^{\text {th }}$ March in EA and from $8^{\text {th }}$ to $12^{\text {th }}$ March 2018 in RA. To control the possible contamination, travel blank filters were used and kept at the same box as the studied filters and kept at the temperature $-20^{\circ} \mathrm{C}$ until the chemical analyses performed. Both studied and blank filters were covered by aluminum foil and put in the zip-lock plastic bag during traveling time to/from the sampling site.

\subsection{Carbon Analyses}

To obtain the carbon content in the size-fractionated particle in Padang city, a thermal/optical carbon analyzer (Model $5 \mathrm{~L}$, Sunset Instruments Inc., USA) has been used following by Interagency Monitoring of Protected Visual Environments-Thermal/Optical Reflectance (IMPROVE-TOR) protocol. This method could specify four OC fractions as OC1 $\left(120^{\circ} \mathrm{C}\right), \mathrm{OC} 2\left(250^{\circ} \mathrm{C}\right), \mathrm{OC} 3\left(450^{\circ} \mathrm{C}\right)$, and $\mathrm{OC} 4\left(550^{\circ} \mathrm{C}\right)$ and three different components of EC i.e. EC1 $\left(550^{\circ} \mathrm{C}\right), \mathrm{EC} 2$ $\left(700^{\circ} \mathrm{C}\right)$, and $\mathrm{EC} 3\left(800^{\circ} \mathrm{C}\right)$ (Han et al., 2007). The OC analyses were performed in pure helium $(\mathrm{He})$ atmosphere while the $\mathrm{EC}$ was done in a mixture of $\mathrm{O} 2(2 \%)$ and $\mathrm{He}(98 \%)$ carrier gas (Watson et al., 2009). Furthermore, the pyrolysis organic carbon (PyOC) was determined after the reflected laser light gained its original intensity after $\mathrm{O}_{2}$ added to the experimental atmosphere.

The total $\mathrm{OC}$ is $\mathrm{OC} 1+\mathrm{OC} 2+\mathrm{OC} 3+\mathrm{OC} 4+\mathrm{PyOC}$ while the total $\mathrm{EC}$ is $\mathrm{EC} 1$ $+\mathrm{EC} 2+\mathrm{EC} 3-\mathrm{PyOC}$. The char EC (EC1-PyOC) and soot-EC (EC2 + EC3) were also discussed in this study. The quality assurance and quality control (QA/QC) for carbon analysis were calibrated with a reference standard and blank filters. A 
reference chemical i.e. sucrose $\mathrm{C}_{12} \mathrm{H}_{22} \mathrm{O}_{11}$ ) (196-00015, Sucrose, Wako Pure Chemical Industries, Ltd., Japan) was used for the calibration of carbon analyses while the blank filter was used to determine the minimum detection limit (MDLs) which is 0.9 and $0.02 \mu \mathrm{g} / \mathrm{cm}^{2}$ for OC and EC, respectively. It means, those values were confirmed to be small enough to a filter blank value.

\subsection{Hotspot and Backward Trajectory Analyses}

Open biomass burning as the sources of PMs also discuss by using the information detected by real-time hotspots from the Moderate Resolution Imaging Spectroradiometer (MODIS) satellite remote sensing imagery (available from http://earthdata.nasa.gov/data/near-real-time-data/firms) provided by US NASA (NASA, 2021). To examine the long air mass transport for the last 72-hour to the sampling site at 500 meters from the above ground level (to ensure the air mass from the sources arriving sampling sites was in the planetary boundary layer $(\mathrm{PBL})$ ), backward trajectory data evaluated by using the HYbrid Single-Particle Lagrangian Integrated Trajectory Model version-4 (HYSPLIT4) (ALR, 2020) were used in this study.

\section{Result and Discussion}

\subsection{Mass Concentration of Fractionated Particles}

Mass concentrations of the size-segregated aerosol particle with their mean, standard deviations, minimum and maximum as well as their ratio in educational (EA) and residential (RA) areas are given in Table 1. The average mass concentration of each size fraction of particles is illustrated in Figure 2(a). PMs with different sizes were divided into six modes according to cut-off sizes of impactor stages, namely $\mathrm{PM}_{>10}, \mathrm{PM}_{10-2.5}, \mathrm{PM}_{2.5-1}, \mathrm{PM}_{1-0.5}, \mathrm{PM}_{0.5-0.1}, \mathrm{PM}_{0.1}$. The magnitudes of all particle size distribution of mass concentration in EA and RA have distinct peaks in the second stage $(2.5-10 \mu \mathrm{m})$. As shown in Figure 2(b), the fine and coarse particle mode $(>1 \mu \mathrm{m})$ was dominated the particle distribution in both sites. The PM level in RA was larger than that in EA. It might be attributed to the RA site location closer to pollutant sources as cement factory and Padang
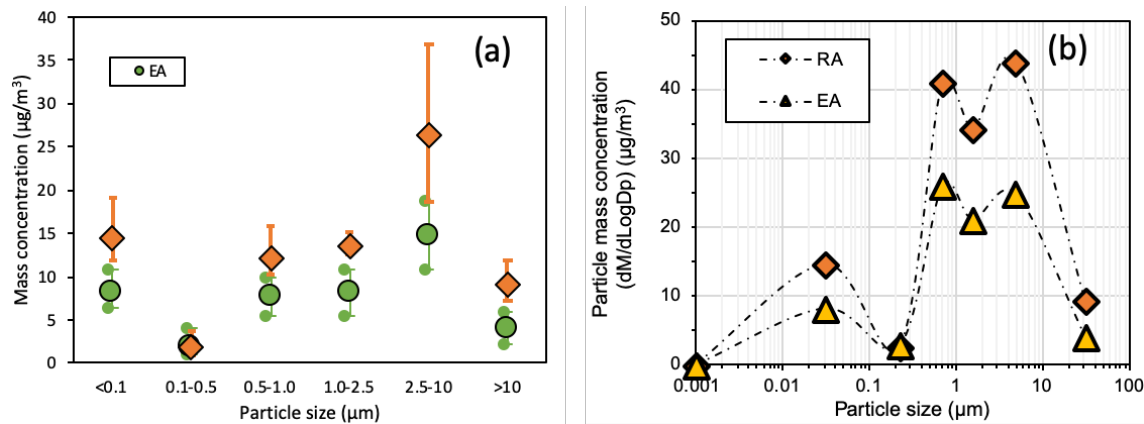

Figure 2. The average mass concentration of each size fraction of particles (a) and particle size distribution $(\mathrm{dM} / \mathrm{d} \log \mathrm{Dp})(\mathrm{b})$ at educational (EA) and residential (RA) area of Padang city. 
Table 1. Size-segregated particle mass concentration and their ratio in educational (EA) and residential (RA) area of Padang city.

\begin{tabular}{|c|c|c|c|c|c|c|}
\hline \multirow{2}{*}{ Parameter } & \multicolumn{3}{|c|}{ Educational area $(\mathrm{EA})\left(\mu \mathrm{g} / \mathrm{m}^{3}\right)$} & \multicolumn{3}{|c|}{ Residential area (RA) $\left(\mu \mathrm{g} / \mathrm{m}^{3}\right)$} \\
\hline & Ave \pm stdev & Min & $\operatorname{Max}$ & Ave \pm stdev & Min & Max \\
\hline \multicolumn{7}{|c|}{ Size distribution $(\mathrm{mm})$} \\
\hline$<0.1$ & $8.17 \pm 1.48$ & 6.39 & 10.85 & $14.56 \pm 3.22$ & 11.95 & 19.08 \\
\hline $0.1-0.5$ & $1.89 \pm 0.94$ & 1.00 & 4.10 & $1.85 \pm 1.10$ & 0.82 & 3.62 \\
\hline $0.5-1.0$ & $7.78 \pm 1.63$ & 5.52 & 9.91 & $12.31 \pm 2.25$ & 10.28 & 15.79 \\
\hline $1.0-2.5$ & $8.36 \pm 1.52$ & 5.54 & 10.85 & $13.59 \pm 1.07$ & 12.59 & 15.20 \\
\hline $2.5-10$ & $14.89 \pm 2.39$ & 10.72 & 18.78 & $26.41 \pm 7.08$ & 18.62 & 36.86 \\
\hline$>10$ & $4.02 \pm 0.97$ & 2.23 & 5.91 & $9.13 \pm 1.80$ & 7.20 & 11.93 \\
\hline \multicolumn{7}{|c|}{ PM } \\
\hline $\mathrm{PM}_{0.1}$ & $8.17 \pm 1.48$ & 6.39 & 10.85 & $14.56 \pm 3.22$ & 11.95 & 19.08 \\
\hline $\mathrm{PM}_{1}$ & $17.85 \pm 3.36$ & 12.95 & 22.91 & $28.71 \pm 3.84$ & 23.23 & 33.29 \\
\hline $\mathrm{PM}_{2.5}$ & $26.21 \pm 4.54$ & 21.29 & 33.76 & $42.30 \pm 4.70$ & 35.82 & 48.49 \\
\hline $\mathrm{PM}_{10}$ & $41.10 \pm 4.96$ & 35.62 & 52.54 & $68.71 \pm 10.99$ & 58.72 & 85.35 \\
\hline TSP & $45.12 \pm 5.27$ & 37.86 & 56.08 & $77.84 \pm 12.46$ & 65.92 & 97.28 \\
\hline \multicolumn{7}{|c|}{ PM ratio } \\
\hline $\mathrm{PM}_{0.1} / \mathrm{PM}_{1}$ & $0.46 \pm 0.03$ & 0.41 & 0.50 & $0.50 \pm 0.06$ & 0.41 & 0.57 \\
\hline $\mathrm{PM}_{0.1} / \mathrm{PM}_{2.5}$ & $0.31 \pm 0.02$ & 0.28 & 0.35 & $0.34 \pm 0.05$ & 0.28 & 0.39 \\
\hline $\mathrm{PM}_{0.1} / \mathrm{PM}_{10}$ & $0.20 \pm 0.03$ & 0.17 & 0.24 & $0.21 \pm 0.03$ & 0.17 & 0.25 \\
\hline $\mathrm{PM}_{0.1} / \mathrm{TSP}$ & $0.18 \pm 0.02$ & 0.15 & 0.21 & $0.19 \pm 0.03$ & 0.15 & 0.23 \\
\hline $\mathrm{PM}_{1} / \mathrm{PM}_{2.5}$ & $0.68 \pm 0.04$ & 0.61 & 0.74 & $0.68 \pm 0.02$ & 0.65 & 0.71 \\
\hline $\mathrm{PM}_{1} / \mathrm{PM}_{10}$ & $0.43 \pm 0.05$ & 0.35 & 0.51 & $0.42 \pm 0.04$ & 0.39 & 0.46 \\
\hline $\mathrm{PM}_{1} / \mathrm{TSP}$ & $0.39 \pm 0.05$ & 0.31 & 0.46 & $0.37 \pm 0.04$ & 0.33 & 0.41 \\
\hline $\mathrm{PM}_{2.5} / \mathrm{PM}_{10}$ & $0.64 \pm 0.06$ & 0.56 & 0.72 & $0.62 \pm 0.05$ & 0.57 & 0.68 \\
\hline $\mathrm{PM}_{2.5} / \mathrm{TSP}$ & $0.58 \pm 0.05$ & 0.51 & 0.65 & $0.55 \pm 0.05$ & 0.50 & 0.61 \\
\hline $\mathrm{PM}_{10} / \mathrm{TSP}$ & $0.91 \pm 0.02$ & 0.89 & 0.94 & $0.88 \pm 0.01$ & 0.86 & 0.89 \\
\hline
\end{tabular}

Besi street while the EA site was located inside the Andalas University which located at the top of Limau Manis hills that is rather isolated from surrounding sources by green belt trees (see Figure 1).

The PMs concentrations in Padang city further compare to the WHO guidelines. Compare to the standard both in particular for $\mathrm{PM}_{2.5}\left(25 \mu \mathrm{g} / \mathrm{m}^{3}\right)$ and $\mathrm{PM}_{10}$ $\left(50 \mu \mathrm{g} / \mathrm{m}^{3}\right)$ in ambient air for 24 hours, exceeded in all days for RA site which ranged from $35.82-48.49 \mu \mathrm{g} / \mathrm{m}^{3}$ and $58.72-85.35 \mu \mathrm{g} / \mathrm{m}^{3}$ for the $\mathrm{PM}_{2.5}$ and $\mathrm{PM}_{10}$, respectively (see Table 1) (WHO, 2006). In order, the average level of those two PMs in RA site was $42.30 \pm 4.70$ and $68.71 \pm 10.99 \mu \mathrm{g} / \mathrm{m}^{3}$ which are comparable to the concentration in the residential area of Bangkok, Thailand at $40.9 \pm 21.4$; $41.5 \pm 24.6$ and $61 \pm 25.2 ; 62.1 \pm 30.7 \mu \mathrm{g} / \mathrm{m}^{3}$ respectively for $\mathrm{PM}_{2.5}$ and $\mathrm{PM}_{10}$ 
(Chuersuwan et al., 2008) and $\mathrm{PM}_{2.5}$ in Malaysia $\left(40.25-43.86 \mu \mathrm{g} / \mathrm{m}^{3}\right.$ ), and a bit lower than $\mathrm{PM}_{10}$ in Malaysia (101.83 - $102.47 \mu \mathrm{g} / \mathrm{m}^{3}$ ) (Azyan et al., 2018). However, those levels in EA could still acceptable since $\mathrm{PM}_{2.5}$ and $\mathrm{PM}_{10}$ average values were $26.21 \pm 4.54$ and $41.10 \pm 4.96 \mu \mathrm{g} / \mathrm{m}^{3}$, respectively. Compare to other developed countries in Asia as Kanazawa, Suzu, and Saitama city in Japan (Hongtieab et al., 2020) the level of $\mathrm{PM}_{2.5}$ and $\mathrm{PM}_{10}$ in EA much higher. Nonetheless, as to the NAAQs of Indonesia, the level $\mathrm{PM}_{2.5}$ and $\mathrm{PM}_{10}$ limit for 24-hours in Padang city were still acceptable. Hereinafter, the range of $\mathrm{PM}_{1}$ level in RA was varied from 23.23 - $33.29 \mu \mathrm{g} / \mathrm{m}^{3}$ which the mean level was $28.71 \pm 3.84 \mu \mathrm{g} / \mathrm{m}^{3}$. Even there is no guideline for this particle size, it could be considered as a high concentration particularly in the RA site since it was still higher compared to the standard $\mathrm{PM}_{2.5}$ standard from WHO.

Taking into account the ultrafine particle $\left(\mathrm{PM}_{0.1}\right)$ level, it is considered as the second-highest of PM mass concentration after $\mathrm{PM}_{10-2.5}$ (see Figure 2(a)). The minimum, mean, and maximum of $\mathrm{PM}_{0.1}$ in RA were $11.95,14.56 \pm 3.22,19.08$ $\mu \mathrm{g} / \mathrm{m}^{3}$. It was comparable with the $\mathrm{PM}_{0.1}$ in the roadside of Medan city $(13.1 \pm$ $3.8 \mu \mathrm{g} / \mathrm{m}^{3}$ ) (Putri et al., 2021) and a bit higher than $\mathrm{PM}_{0.1}$ in Jambi city (9.2 - 9.6 $\mu \mathrm{g} / \mathrm{m}^{3}$ ) (Amin et al., 2019), Sumatera Island, Indonesia. The high concentration of ultrafine particles could be emitted from the vehicle emission, fresh biomass burning nearby, and coal burning from the cement factory which will discuss in the following section.

\section{2. $\mathrm{PM}_{0.1}$ Ratio}

The $\mathrm{PM}_{0.1}$ ratio in various categories of PMs is listed in Table 1. $\mathrm{PM}_{0.1} / \mathrm{TSP}$ was similar between sites, or, the mean $\mathrm{PM}_{0.1} / \mathrm{TSP}$ was $0.19 \pm 0.03$ and $0.18 \pm 0.02$ respectively at RA and EA sites. Around a half of $\mathrm{PM}_{1}$ in Padang city was considered as ultrafine particles $(0.50 \pm 0.06$ at EA and $0.46 \pm 0.03$ in RA). It comparable with reported values in Japan (0.48 - 0.61) (Hongtieab et al., 2020). Since $\mathrm{PM}_{2.5}$ is more familiar around the world compare to $\mathrm{PM}_{1} \cdot \mathrm{PM}_{0.1}$ in our studies also compare to $\mathrm{PM}_{2.5}$ and the mean ratio in the RA and EA was $0.34 \pm 0.05$ and $0.31 \pm 0.02$, which was quite similar to the ratio in Thailand $(0.28)$ (Phairuang et al., 2019) and much higher than Vietnam (0.08 - 0.11) (Thuy et al., 2018) and Japan (0.15 - 0.21) (Hongtieab et al., 2020), suggested Padang city, Indonesia was more influenced by the smaller particles, particularly in the range of fine particles. It also can be seen from the ratio of $\mathrm{PM}_{1} / \mathrm{PM}_{2.5}$ and $\mathrm{PM}_{2.5} / \mathrm{PM}_{10}$ which much larger than 0.5 in both sites. However, a bit higher coarser fraction in RA compared to EA could be associated with the road dust or fly ash along the material transportation using trucks from the material sources to the cement factory.

\subsection{Carbon Content Concentration}

Carbonaceous components represented the OC, EC, char-EC, soot-EC were shown in Table 2. The fraction OC and EC in both sites were comparable in all 
Table 2. Size segregated carbonaceous component concentration and their ratio in educational (EA) and residential (RA) area of Padang city.

\begin{tabular}{cccccccc}
\hline Size & $\begin{array}{c}\text { OC } \\
\left(\mu \mathrm{g} / \mathrm{m}^{3}\right)\end{array}$ & $\begin{array}{c}\text { EC } \\
\left(\mu \mathrm{g} / \mathrm{m}^{3}\right)\end{array}$ & $\begin{array}{c}\text { OC/EC } \\
(-)\end{array}$ & $\begin{array}{c}\text { Char-EC } \\
\left(\mu \mathrm{g} / \mathrm{m}^{3}\right)\end{array}$ & $\begin{array}{c}\text { Soot-EC } \\
\left(\mu \mathrm{g} / \mathrm{m}^{3}\right)\end{array}$ & $\begin{array}{c}\text { Char-EC/ } \\
\text { Soot-EC }(-)\end{array}$ & $\begin{array}{c}\mathrm{TC} \\
\left(\mu \mathrm{g} / \mathrm{m}^{3}\right)\end{array}$ \\
\cline { 2 - 7 } & & & $\mathrm{EA}$ & & & \\
\hline$<0.1$ & $3.26 \pm 0.8$ & $0.38 \pm 0.1$ & $8.71 \pm 1.7$ & $0.10 \pm 0.0$ & $0.28 \pm 0.1$ & $0.40 \pm 0.3$ & $3.64 \pm 0.8$ \\
$0.5-1$ & $2.93 \pm 3.1$ & $0.56 \pm 0.6$ & $7.04 \pm 5.7$ & $0.25 \pm 0.2$ & $0.32 \pm 0.5$ & $2.02 \pm 1.9$ & $3.50 \pm 3.6$ \\
$1-2.5$ & $2.91 \pm 0.7$ & $0.43 \pm 0.2$ & $7.58 \pm 3.0$ & $0.32 \pm 0.1$ & $0.10 \pm 0.1$ & $3.78 \pm 1.5$ & $3.34 \pm 0.8$ \\
$2.5-10$ & $5.87 \pm 1.3$ & $0.78 \pm 0.3$ & $7.18 \pm 2.5$ & $0.67 \pm 0.3$ & $0.11 \pm 0.0$ & $6.35 \pm 3.7$ & $6.64 \pm 1.3$ \\
$>10$ & $0.79 \pm 0.7$ & $0.08 \pm 0.0$ & $11.55 \pm 6.7$ & $0.06 \pm 0.0$ & $0.02 \pm 0.0$ & $4.84 \pm 3.7$ & $0.87 \pm 0.7$ \\
\hline Size & & & & $\mathrm{RA}$ & & & \\
\hline$<0.1$ & $3.19 \pm 0.4$ & $0.43 \pm 0.1$ & $7.79 \pm 2.4$ & $0.11 \pm 0.1$ & $0.32 \pm 0.0$ & $0.39 \pm 0.4$ & $3.62 \pm 0.3$ \\
$0.5-1$ & $2.63 \pm 0.5$ & $0.52 \pm 0.3$ & $6.30 \pm 3.0$ & $0.32 \pm 0.3$ & $0.20 \pm 0.0$ & $1.49 \pm 1.3$ & $3.15 \pm 0.7$ \\
$1-2.5$ & $3.22 \pm 0.7$ & $0.45 \pm 0.3$ & $11.57 \pm 12.1$ & $0.31 \pm 0.3$ & $0.13 \pm 0.0$ & $2.53 \pm 2.0$ & $3.67 \pm 0.7$ \\
$2.5-10$ & $4.82 \pm 1.5$ & $0.86 \pm 0.4$ & $7.01 \pm 5.1$ & $0.61 \pm 0.4$ & $0.25 \pm 0.0$ & $2.66 \pm 1.5$ & $5.67 \pm 1.8$ \\
$>10$ & $0.70 \pm 0.4$ & $0.12 \pm 0.1$ & $6.97 \pm 2.5$ & $0.09 \pm 0.1$ & $0.03 \pm 0.0$ & $3.51 \pm 1.2$ & $0.82 \pm 0.5$ \\
\hline
\end{tabular}

particle sizes accounted $70.40-96.47 ; 3.53 \%-29.60 \%$ and $72.75-97.06 ; 2.94 \%-$ $27.25 \%$ both at EA and RA, respectively. At both sites, fine fraction (2.5 - 1, 1 0.5 , and $<0.1 \mu \mathrm{m})$ were more enriched by EC than coarser fraction $(2.5-10$ and $>10 \mu \mathrm{m})$. The total EC in fine-coarse in EA and RA was $1.37-0.86 \mu \mathrm{g} / \mathrm{m}^{3}$ and $1.40-0.98 \mu \mathrm{g} / \mathrm{m}^{3}$. It agreed with the previous studies by Guo (2016) which EC more abundance in fine particles since it commonly emitted from vehicle exhaust (Yang et al., 2019; Liu et al., 2020). However, the particle with size 2.5 $10 \mathrm{~mm}$ contained the highest both OC and EC in all sites it might be due to the highest mass concentration among the particle sizes. The highest OC fraction was found in the particle with size 2.5 - $10 \mu \mathrm{m}$ while for the EC, the higher fraction was founded in the particle $0.5-1 \mu \mathrm{m}$. As published by Phairuang et al. (2020) in Hat Yai, Thailand and Amin et al. (2019) in Sumatra, Indonesia, particles with the size $0.5-1 \mu \mathrm{m}$ contained the highest EC among the other sizes.

The OC concentration in $\mathrm{PM}_{0.1}$ varied from 2.54 to $5.06 \mu \mathrm{g} / \mathrm{m}^{3}$ and from 2.73 to $3.64 \mu \mathrm{g} / \mathrm{m}^{3}$ in EA and RA, respectively, notably higher than the concentration in developed countries at 0.10 to $0.14 \mu \mathrm{g} / \mathrm{m}^{3}$ and $0.18 \mu \mathrm{g} / \mathrm{m}^{3}$ for Los Angeles and Central Sacramento, USA respectively (Kuwayama et al., 2013; Xue et al., 2019). On the other hand, the level of EC in $\mathrm{PM}_{0.1}$ mass concentration in both sites were similar $\left(0.30-0.49 \mu \mathrm{g} / \mathrm{m}^{3}\right.$ in EA and $0.30-0.51 \mu \mathrm{g} / \mathrm{m}^{3}$ in RA) which was higher than the previous study by Xue et al. (2019) in Los Angeles (0.03 - 0.05 $\left.\mu \mathrm{g} / \mathrm{m}^{3}\right)$ and by Kuwayama et al. (2013) in Sacramento $\left(0.06 \mu \mathrm{g} / \mathrm{m}^{3}\right)$, USA. Furthermore, even compare to the value in Asian Countries, the EC concentration in $\mathrm{PM}_{0.1}$ was still a bit higher than $\mathrm{PM}_{0.1}$ EC in Hatyai city, Thailand $\left(0.23 \mu \mathrm{g} / \mathrm{m}^{3}\right)$ and Hanoi city, Vietnam $\left(0.25-0.29 \mu \mathrm{g} / \mathrm{m}^{3}\right)$, and Kanazawa, Suzu and Saitama city in Japan $\left(0.07-0.18 \mu \mathrm{g} / \mathrm{m}^{3}\right)$ (Thuy et al., 2018; Hongtieab et al., 2020; Phai- 
ruang et al., 2020).

\subsection{OC/EC and Char-EC/Soot-EC Ratio}

The ratios OC/EC and char-EC/soot-EC are illustrated in Figure 3(a) and Figure 3(b) while the detail value was shown in Table 2. The average OC/EC ratio in all sizes for both sites was comparable since the distance between those two sites was not so far, for just around $\pm 3.41 \mathrm{~km}$ (see Figure 1). The ratios OC/EC in $\mathrm{PM}_{0.1}$ were varied from 2.54 to 5.06 and from 2.73 to 3.64 for EA and RA sites, respectively. The highest ratio of OC/EC in both sites was founded in $\mathrm{PM}_{>10}$ for $\mathrm{EA}$ at $11.55 \pm 6.67$ and in $\mathrm{PM}_{1-2.5}$ for RA sites at $11.57 \pm 12.11$. Overall, the ratio of OC/EC in Padang city in all sizes ranged from 2.38 to 32.98 indicated multiple types of emission sources contributed to both sites as motor vehicles exhaust, coal combustion, and biomass burning and might be attributed to the SOC since all sizes and days was exceeded 2.0 as an indicator of the presence of SOC (Guo, 2016).

Similar to the OC/EC ratio, char-EC/soot-EC ratio as the carbonaceous aerosol sources indicator are widely used even it could be more effective to use than OC/EC ratio since char-EC and soot-EC were not affected by SOC formation (Han et al., 2009). Based on the previous discussion, OC could be formed from SOC while EC only emitted from the primary emission. By using char-EC/soot-EC ratio as sources indicators, biased due to SOC could be ignored. As to these ratios, $\mathrm{PM}_{0.1}$ char-EC/soot-EC ratio was the lowest compare to other particle sizes at $0.40 \pm 0.27$ and $0.39 \pm 0.39$ for EA and RA, respectively suggested that emission from diesel engines was the major contributor to the total EC concentrations (Han et al., 2016) in $\mathrm{PM}_{0.1}$. Then, these two-carbon ratios in other particle sizes were increased particularly in the $\mathrm{PM}_{>10}$ and $\mathrm{PM}_{10-2.5}$ might be correlated to the presence of small-scale open biomass burning surrounding monitoring sites and the influenced of the cement industry that used coal as the main fuels. Published by Kumar and Atri (2016), biomass burning, and coal combustion emitted
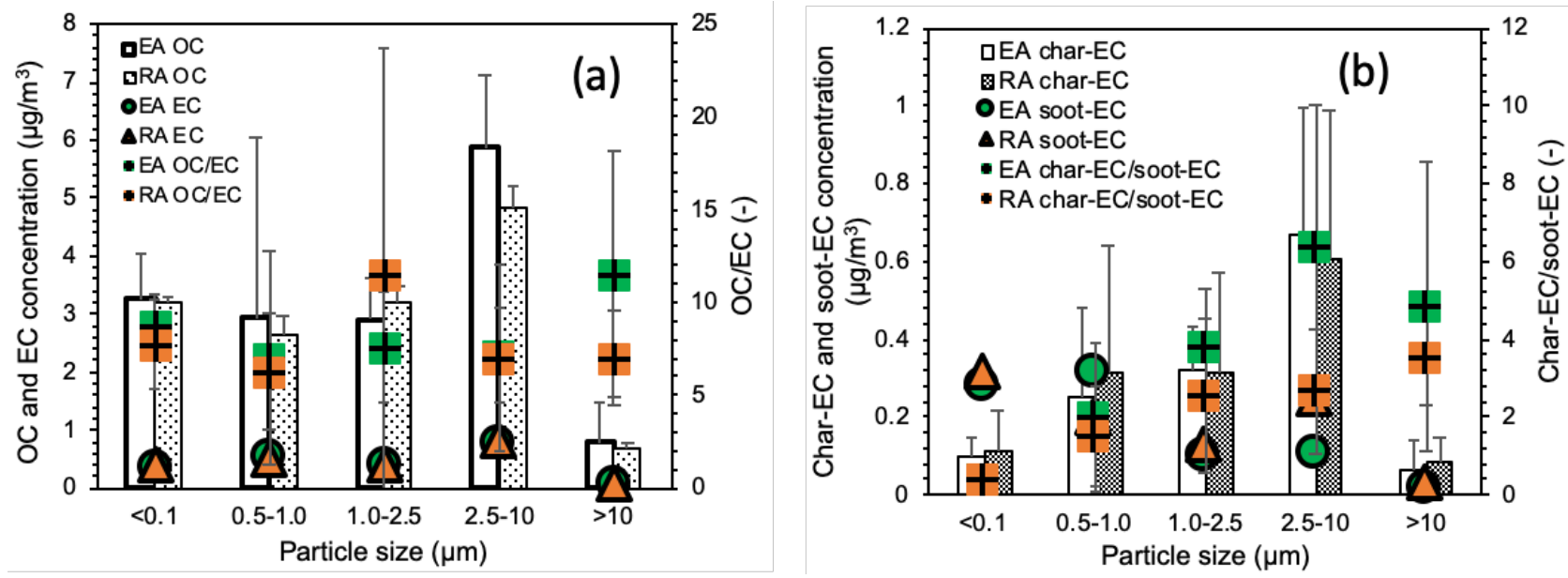

Figure 3. (a) OC and EC concentrations (b) and char-EC and soot-EC concentrations of each size fraction of particles and their ratio in educational (EA) and residential (RA) area of Padang city. 
an abundance of char-EC. For all particle sizes, the char-EC/soot-EC ratio in the EA site much larger than the RA site especially taking into account $\mathrm{PM}_{10-2.5}$ which almost -3 times higher than RA. A lower char-EC/soot-EC ratio in RA for all particle sizes could be correlated to the sampling sites nearby the main street.

\subsection{Correlation between Carbon Components}

The correlation among carbonaceous component in PMs were shown in Table 3. There is no significant correlation between OC and EC in all particle sizes both in EA and RA except in the $\mathrm{PM}_{>10}$ at EA $(\mathrm{r}=0.93)$ and at RA $(\mathrm{r}=0.96)$ sites, suggested OC and EC in both sizes were emitted from the typical sources. For further checking, the char-EC and soot-EC ratio also plotted together with the OC. In the same size of particles, i.e. $\mathrm{PM}_{>10}$, a moderate and good correlation between char-EC and soot-EC with the OC were found in both sites. Not only in the $\mathrm{PM}_{>10}$, even for all particle size, but also we found that soot-EC has a good correlation with OC in the RA sites, might be related to the emission from vehicles and the cement industry which high temperature applied as in the kiln process where the temperature could up to $\pm 1450^{\circ} \mathrm{C}$. The same trend was found in the EA site where the soot-EC correlation with OC was more significant than the char-EC relationship with OC particularly in the fine and ultrafine sizes (Kim et al., 2011) suggested the emission from cement factory or roadside nearby were influenced EA site. In the $\mathrm{PM}_{0.1}$, the negative and insignificant correlation between char-EC and soot-EC were found in both sites while for $\mathrm{PM}_{>10}$, it showed a positive correlation with $\mathrm{r}$ value at 0.58 and 0.99 for EA and RA sites, respectively, indicated char-EC and soot-EC in ultrafine particles in both sites came from different sources.

\subsection{Long Range Transportation}

To examine the effect of long-range transportation of aerosol particles to Padang city. Backward air mass trajectory to both sampling sites was discussed in this study and illustrated in Figure 4 regarding the air parcel movement, the air

Table 3. Pearson correlation among carbonaceous components in educational (EA) and residential (RA) area of Padang city.

\begin{tabular}{|c|c|c|c|c|c|c|c|c|c|c|}
\hline \multirow{3}{*}{$\begin{array}{c}\text { Carbon } \\
\text { component }\end{array}$} & \multicolumn{5}{|c|}{ EA } & \multicolumn{5}{|c|}{ RA } \\
\hline & \multicolumn{5}{|c|}{ OC } & \multicolumn{5}{|c|}{ OC } \\
\hline & $\begin{array}{l}0.1 \\
\mu \mathrm{m}\end{array}$ & $\begin{array}{c}0.5-1 \\
\mu \mathrm{m}\end{array}$ & $\begin{array}{c}1-2.5 \\
\mu \mathrm{m}\end{array}$ & $\begin{array}{c}2.5-10 \\
\mu \mathrm{m}\end{array}$ & $\begin{array}{l}>10 \\
\mu \mathrm{m}\end{array}$ & $\begin{array}{l}0.1 \\
\mu \mathrm{m}\end{array}$ & $\begin{array}{c}0.5-1 \\
\mu \mathrm{m}\end{array}$ & $\begin{array}{c}1-2.5 \\
\mu \mathrm{m}\end{array}$ & $\begin{array}{c}2.5-10 \\
\mu \mathrm{m}\end{array}$ & $\begin{array}{l}>10 \\
\mu \mathrm{m}\end{array}$ \\
\hline $\mathrm{EC}$ & 0.69 & 0.32 & 0.22 & 0.52 & 0.93 & -0.55 & 0.35 & -0.28 & 0.52 & 0.96 \\
\hline Char-EC & -0.79 & 0.23 & -0.79 & 0.54 & 0.59 & -0.77 & 0.27 & -0.39 & 0.40 & 0.96 \\
\hline \multirow[t]{2}{*}{ Soot-EC } & 0.98 & 0.83 & 0.94 & -0.26 & 0.97 & 0.70 & 0.95 & 0.97 & 0.57 & 0.97 \\
\hline & \multicolumn{5}{|c|}{ Char-EC } & \multicolumn{5}{|c|}{ Char-EC } \\
\hline Soot-EC & 0.30 & 0.63 & -0.53 & 0.20 & 0.58 & -0.60 & 0.52 & -0.15 & -0.32 & 0.99 \\
\hline
\end{tabular}




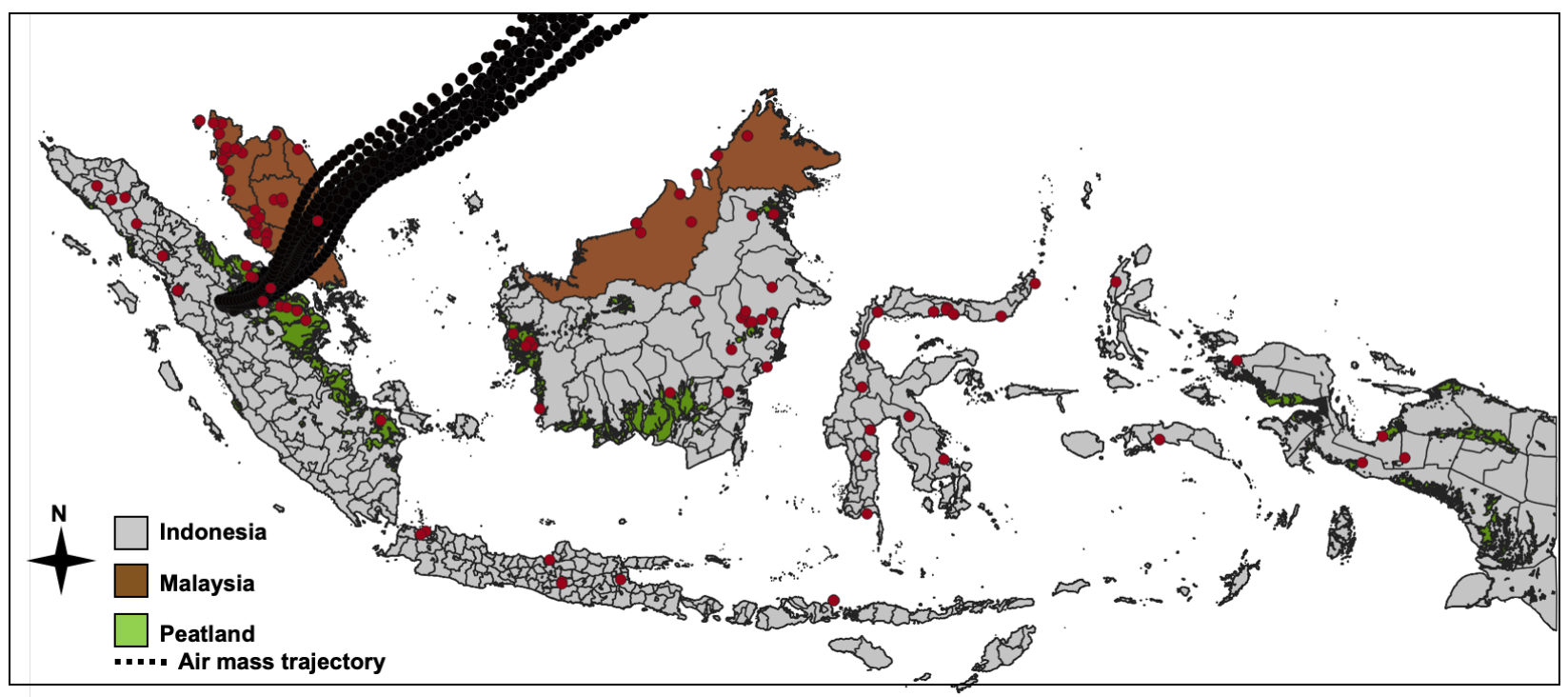

Figure 4. Hotspots distribution and air mass trajectories arriving at study sites.

mass came from the South China Sea passed through the neighboring province (Riau province). Riau province is one of the biggest contributors of aerosol particles since this province has a lot of peatland area which is very easy to burn particularly during dry season. However, since our samples were taken in the rainy season, biomass burning which represented by hotspot was not so important although it could not be ignored because the air mass that comes to sampling sites was passing through a small number of hotspots in Riau province. Then, the local emission as vehicle exhaust, coal burning together with biomass burning nearby sampling sites might be the main sources of the aerosol particle in both two sites.

\section{Conclusion}

Distinct variation of size-segregated of PMs bound carbonaceous component including ultrafine particle by using a cascade air sampler were observed in educational (EA) and residential (RA) area in Padang city, West Sumatera Province, Indonesia. The average PM concentration was higher in RA than in EA sites since it is closer to the main sources of air pollutants in that region i.e. Cement Factory, Padang Basi Street and, biomass burning in the residential area. The mean level of $\mathrm{PM}_{2.5}$ and $\mathrm{PM}_{10}$ in RA were exceeded the WHO limit however those values were still acceptable compared to the NAAQS of Indonesia. Based on the carbon component, OC dominated the TC in all particle sizes and sites. The ratio of OC to EC ranged from 2.38 to 32.98 indicated multiple sources as vehicle exhaust emission, coal combustion, biomass burning and might be secondary organic carbon (SOC) since the OC/EC ratio mostly higher than 2.0. Furthermore, as to char-EC/soot-EC, it is clear to note that vehicle exhaust was the main source of carbon aerosol in ultrafine particles due to its ratio lower than 1. Based on the air mass trajectory, the contribution of transboundary open 
biomass burning to the Padang city during sampling time was not important. Nonetheless, it could not be negligible since it was passing through the low number of hotspots in the Riau province. Hence, the local emission should be the main PMs sources in Padang city, Indonesia.

\section{Acknowledgements}

The authors gratefully acknowledge the contribution of the members of the East Asia Nanoparticle Monitoring Network (EA-NanoNet) for field sampling particularly members in Padang city, Indonesia

\section{Conflicts of Interest}

The authors have no conflicts of interest to declare.

\section{References}

Adam, M. G., Tran, P. T. M., Bolan, N., \& Balasubramanian, R. (2021). Biomass Burning-Derived Airborne Particulate Matter in Southeast Asia: A Critical Review. Journal of Hazardous Materials, 407, Article ID: 124760. https://doi.org/10.1016/j.jhazmat.2020.124760

Air Resource Laboratory (ALR) (2020). The Air Resource Laboratory (HYSPLIP 4). http://ready.arl.noaa.gov/HYSPLIT.php

Amin, M., Putri, R. M., Piriyakarnsakul, S., Handika, R. A., Ullah, A., Phairuang, W., Ikemori, F., Hata, M., \& Furuuchi, M. (2019). Size-Segregated Particulate Matter down to $\mathrm{PM}_{011}$ and Carbon Content during a Haze Episode in Sumatra Island, Indonesia. Proc. the 18th World Clean Air Congress 2019(Vol. 244), Istanbul.

Azyan, Z. M. Z. Nurul, N. A. A. M., \& Jalina, K. (2018). Particulate Matter Study at Residential and Educational Areas in Shah Alam, Malaysia. MATEC Web of Conferences, 250, Article ID: 06010. https://doi.org/10.1051/matecconf/201825006010

Bachtiar, V. S., Ruslinda, Y., Wangsa, D., \& Kurniawan, E. (2016). Mapping of $\mathrm{PM}_{10}$ Concentrations and Metal Source Identifications in Air Ambient at Surrounding Area of Padang Cement Factory. Journal of Environmental Science and Technology, 9, 390-398. https://doi.org/10.3923/jest.2016.390.398

Badan Pusat Statistik (BPS-Statistics of Padang City) (2019). Padang City in Figure. Padang, Indonesia: BPS.

Chuersuwan, N., Nimrat, S., Lekphet, S., \& Kerdkumrai, T. (2008). Levels and Major Sources of $\mathrm{PM}_{2.5}$ and $\mathrm{PM}_{10}$ in Bangkok Metropolitan Region. Environment International, 34, 671-677. https://doi.org/10.1016/j.envint.2007.12.018

Fujii, Y., Huboyo, H. S., Tohno, S., Okuda, T., \& Syafrudin (2019). Chemical Speciation of Water-Soluble Ionic Components in $\mathrm{PM}_{2.5}$ Derived from Peatland Fires in Sumatra Island. Atmospheric Pollution Research, 10, 1260-1266. https://doi.org/10.1016/j.apr.2019.02.009

Furuuchi, M., Eryu, K., Nagura, M., Hata, M., Kato, T., Tajima, N., Sekiguchi, K., Ehara, K., Seto, T., \& Otani, Y. (2010). Development and Performance Evaluation of Air Sampler with Inertial Filter for Nanoparticle Sampling. Aerosol and Air Quality Research, 10, 185-192. https://doi.org/10.4209/aaqr.2009.11.0070

Guo, Y. H. (2016). Characteristics of Size-Segregated Carbonaceous Aerosols in the Beijing-Tianjin-Hebei Region. Environmental Science and Pollution Research, 23, 13918 13930. https://doi.org/10.1007/s11356-016-6538-Z 
Han, Y. M., Cao, J., Chow, J. C., \& Watson, J. G. (2007). Evaluation of the Thermal/Optical Reflectance Method for Discrimination between Char- and Soot-EC. Chemosphere, 69, 569-574. https://doi.org/10.1016/j.chemosphere.2007.03.024

Han, Y. M., Chen, L. W., Huang, R. J., Chow, J. C., Watson, J. G., Ni, H. Y., Liu, S. X., Fung, K. K., Shen, Z. X., Wei, C., Wang, Q., Tian, J., Zhao, Z., Prevot, A., \& Cao, J. J. (2016). Carbonaceous Aerosols in Megacity Xi'an, China: Implications of Thermal/Optical Protocols Comparison. Atmospheric Environment, 132, 58-68.

https://doi.org/10.1016/j.atmosenv.2016.02.023

Han, Y. M., Lee, S. C., Cao, J. J., Ho, K. F., \& An, Z. S. (2009). Spatial Distribution and Seasonal Variation of Char-EC and Soot-EC in the Atmosphere over China. Atmos pheric Environment, 43, 6066-6073. https://doi.org/10.1016/j.atmosenv.2009.08.018

Hongtieab, S., Yoshikawa, F., Matsuki, A., Zhao, T., Amin, M., Hata, M., Tekasakul, P., \& Furuuchi, M. (2020). Seasonal Behavior and Emission Sources of Ambient PM $M_{0.1}$ in the Hokuriku Region in Japan, Japan Sea Research. (In Press)

Kim, K. H., Sekiguchi, K., Kudo, S., \& Sakamoto, K., (2011). Characteristics of Atmospheric Elemental Carbon (Char and Soot) in Ultrafine and Fine Particles in a Roadside Environment, Japan. Aerosol and Air Quality Research, 11, 1-12. https://doi.org/10.4209/aaqr.2010.07.0061

Kumar, A., \& Atri, A. K. (2016). Biomass Combustion a Dominant Source of Carbonaceous Aerosols in the Ambient Environment of Western Himalayas. Aerosol and Air Quality Research, 16, 519-529. https://doi.org/10.4209/aaqr.2015.05.0284

Kusumaningtyas, S., Aldrian, E., Wati, T., \& Atmoko, D. (2018). The Recent State of Ambient Air Quality in Jakarta. Aerosol and Air Quality Research, 18, 2343-2354. https://doi.org/10.4209/aaqr.2017.10.0391

Kuwayama, T., Ruehl, C. R., \& Kleeman, M. J. (2013). Daily Trends and Source Apportionment of Ultrafine Particulate Mass $\left(\mathrm{PM}_{0.1}\right)$ over an Annual Cycle in a Typical California City. Environmental Science \& Technology, 47, 13957-13966. https://doi.org/10.1021/es403235c

Liu, X., Kong, S., Yan, Q., Liu, H., Wang, W., Chen, K., Yin, Y., Zheng, H., Wu, J., Qin, S., Liu, J., Feng, Y., Yan, Y., Liu, D., Zhao, D., \& Qi, S. (2020). Size-Segregated Carbonaceous Aerosols Emission from Typical Vehicles and Potential Depositions in the $\mathrm{Hu}$ man Respiratory System. Environmental Pollution, 264, Article ID: 114705. https://doi.org/10.1016/j.envpol.2020.114705

Manisalidis, I., Stavropoulou, E., Stavropoulos, A., \& Bezirtzoglou, E. (2020). Environmental and Health Impacts of Air Pollution: A Review. Front. Public Health, 8. https://doi.org/10.3389/fpubh.2020.00014

Ministry of Environment of Japan (MOE) (2019). Chapter 4. Carbonous Component Analysis Method (Thermal Optical Reflectance Method). In Fine Particles (PM 2.5$)$ Component Measurement Manual (3rd ed.). (In Japanese)

https://www.env.go.jp/air/ose n/pm/ca/manual.html

NASA (National Aeronautics and Space Administration) (2021). https://earthdata.nasa.gov/earth-observation-data/near-real-time/firms

Oanh, N. T. K., Permadi, D. A., Hopke, P. K., Smith, K. R., Dong, N. P., \& Dang, A. N. (2018). Annual Emissions of Air Toxics Emitted from Crop Residue Open Burning in Southeast Asia over the Period of 2010-2015. Atmospheric Environment, 187, 163-173. https://doi.org/10.1016/j.atmosenv.2018.05.061

Phairuang, W., Inerb, M., Furuuchi, M., Hata, M., Tekasakul, S., \& Tekasakul, P. (2020). Size-Fractionated Carbonaceous Aerosols down to $\mathrm{PM}_{0.1}$ in Southern Thailand: Local and Long-Range Transport Effects. Environmental Pollution, 260, Article ID: 114031. 
https://doi.org/10.1016/j.envpol.2020.114031

Phairuang, W., Suwattiga, P., Chetiyanukornkul, T., Hongtieab, S., Limpaseni, W., Ikemori, F., Hata, M., \& Furuuchi, M. (2019). The Influence of the Open Burning of Agricultural Biomass and Forest Fires in Thailand on the Carbonaceous Components in Size-Fractionated Particles. Environmental Pollution, 247, 238-247. https://doi.org/10.1016/j.envpol.2019.01.001

Putri, R. M., Amin, M., Suciari, T. F., Faisal, A. F. M., Auliani, R., Ikemori, F., Wada, M., Hata, M., Tesakul, P., \& Furuuchi, M. (2021). Site-Specific Variation in Mass Concentration and Chemical Components in Ambient Nanoparticles $\left(\mathrm{PM}_{0.1}\right)$ in North Sumatra Province-Indonesia. Atmospheric Pollution Research, 12, 101062.

https://doi.org/10.1016/j.apr.2021.101062

Reddington, C. L., Conibear, L., Knote, C., Silver, B. J., Li, Y. J., Chan, C. K., Arnold, S. R., \& Spracklen, D. V. (2019). Exploring the Impacts of Anthropogenic Emission Sectors on $\mathrm{PM}_{2.5}$ and Human Health in South and East Asia. Atmospheric Chemistry and Physics, 19, 11887-11910. https://doi.org/10.5194/acp-19-11887-2019

Tao, J., Zhang, Z., Zhang, L., Wu, Y., Zhang, R., \& Wang, B. (2021). Impact of Deliquescence of Aerosol on Mass Absorption Efficiency of Elemental Carbon in Fine Particles in Urban Guangzhou in South China. Atmospheric Environment, 256, Article ID: 118476. https://doi.org/10.1016/j.atmosenv.2021.118476

Thuy, N. T. T., Dung, N. T., Sekiguchi, K., Thuy, L. B., Hien, N. T. T., \& Yamaguchi, R. (2018). Mass Concentrations and Carbonaceous Compositions of PM0.1, PM2.5, and PM10 at Urban Locations of Hanoi, Vietnam. Aerosol Air Qual. Res, 18, 1591-1605. https://doi.org/10.4209/aaqr.2017.11.0502

Watson, J. G., Chow, J. C., \& Chen, L. W. A. (2009). Methods to Assess Carbonaceous Aerosol Sampling Artifacts for IMPROVE and Other Long-Term Networks. J. Air Waste Manag. Assoc, 59, 898-911. https://doi.org/10.3155/1047-3289.59.8.898

World Health Organization (WHO) (2006). Air Quality Guidelines for Particulate Matter, Ozone, Nitrogen Dioxide and Sulfur Dioxide, Summary of Risk Assessment. WHO Press.

Xue, J., Xue, W., Sowlat, M. H., Sioutas, C., Lolinco, A., Hasson, A., \& Kleeman, M. J. (2019). Seasonal and Annual Source Appointment of Carbonaceous Ultrafine Particulate Matter $\left(\mathrm{PM}_{0.1}\right)$ in Polluted California Cities. Environ. Sci. Tech, 53, 39-49. https://doi.org/10.1021/acs.est.8b04404

Yang, H. H., Dhital, N. B., Wang, L. C., Hsieh, Y. S., Lee, K. T., Hsu, Y. T., \& Huang, S. C. (2019). Chemical Characterization of Fine Particulate Matter in Gasoline and Diesel Vehicle Exhaust. Aerosol and Air Quality Research, 19, 1439-1449. https://doi.org/10.4209/aaqr.2019.04.0191

Zhang, F., Guo, H., Chen, Y., Matthias, V., Zhang, Y., Yang, X., \& Chen, J. (2020). Size-Segregated Characteristics of Organic Carbon (OC), Elemental Carbon (EC) and Organic Matter in Particulate Matter (PM) Emitted from Different Types of Ships in China. Atmos. Chem. Phys., 20, 1549-1564. https://doi.org/10.5194/acp-20-1549-2020 